\title{
Electrospray Low Energy CID and MALDI PSD Fragmentations of Protonated Sulfinamide Cross-linked Peptides
}

\author{
Mark J. Raftery and Carolyn L. Geczy \\ Cytokine Research Unit, School of Medical Sciences, University of New South Wales, Kensington, New South \\ Wales, Australia
}

\begin{abstract}
Murine S100A8 (A8) is a major cytoplasmic neutrophil protein and is converted to novel oxidation products containing Cys- $\varepsilon$ amino-Lys sulfinamide cross-links and Met-sulfoxide by the neutrophil oxidant HOCl. Seven products were separated using RP-HPLC, with electrospray ionization mass spectrometry (ESI-MS) masses after deconvolution of 10,354, 10,388, \pm 1 , and $20,707, \pm 3 \mathrm{Da}$, and all were resistant to reduction by dithiothreitol. The major products with masses of 10,354 Da contained $\mathrm{Cys}_{41}-\mathrm{Lys}_{34 / 35}$ intramolecular cross-links. Additional isomeric products with identical masses $(10,354 \mathrm{Da})$ were isolated and peptide mapping and ESI/MS indicated that Cys ${ }_{41}$ forms covalent sulfinamide cross-links with either Lys $_{6}$, Lys $_{76}$, $\mathrm{Lys}_{83}$, or $\mathrm{Lys}_{87}$ present in A8. Electrospray low energy collisionally induced (CID) spectra of multiply-charged AspN digest peptides with sulfinamide cross-links contained characteristic fragmentations that corresponded to simple cleavage of the nitrogen-sulfur bond with charge retention on either of the fragment ions, allowing conformation of cross-linked peptides. Matrix-assisted laser desorption/ionization time-of-flight (MALDI-TOF) post source decay spectra of $[\mathrm{M}+\mathrm{H}]^{+}$ions of the same sulfinamide-containing cross-linked peptides fragment similarly, but additional facile fragmentation reactions corresponding to formation of a protonated peptide containing de-hydroalanine were attributed to cleavage of the carbon-sulfur bond. In addition, lose of methanesulfenic acid from Met-sulfoxide was observed. A sulfinamide-containing adduct was isolated after incubation of the $\mathrm{A} 8 / \mathrm{HOCl}$ reaction mixture with Lys or $\alpha \mathrm{N}$-acetyl Lys with masses of 10,500 or 10,542 Da. ESI/MS/MS and MALDI/ post decay source (PSD) analysis of $\mathrm{A} 8_{32-57}$-sulfinamide showed the same characteristic fragmentations as those in the sulfinamide cross-linked peptides, confirming the $\mathrm{Cys}_{41}$-Lys sulfinamide cross-link and suggesting that peptide-peptide sulfinamides may all fragment similarly, allowing ready identification of these cross-links in proteins from more complex biological materials. (J Am Soc Mass Spectrom 2002, 13, 709-718) () 2002 American Society for Mass Spectrometry
\end{abstract}

S 100 calcium-binding proteins are a family of 18 highly conserved, small ( $\sim 10 \mathrm{kDa})$ acidic proteins with important regulatory functions including regulation of kinases, suppression of tumor progression, embryogenesis, and cell migration [1-5]. S100A8 (A8) has chemotactic activity for leukocytes [6] although other studies indicate additional roles [4, 7], possibly related to regulating inflammation, when present at high levels. S100 proteins form non-covalent homodimers characterized by a symmetric homodimeric fold not found in other $\mathrm{Ca}^{2+}$-binding proteins, in solution. Non-covalent A8 homodimers were also observed using mass spectrometry [8]. $\mathrm{Ca}^{2+}$ binding induces structural changes within helices III and IV, exposing amino acids within the hinge and

Published online April 23, 2002

Address reprint requests to Dr. M. J. Raftery, Cytokine Research Unit, School of Medical Sciences, University of New South Wales, Kensington, New South Wales 2052, Australia. E-mail: m.raftery@unsw.edu.au
C-terminal domains that may be involved in binding target proteins $[5,9]$. Covalent oxidative modifications may regulate the functions of $\mathrm{S} 100 \mathrm{~B}, \mathrm{~A} 8$, and $\mathrm{S} 100 \mathrm{~A} 2$ [10-12].

Neutrophils (PMN) release reactive oxygen species formed via the NADPH oxidase complex following activation with agents such as phorbol 12-myristate 13-acetate (PMA) and chemoattractants [13]. The respiratory burst produces superoxide anions which dismutate to hydrogen peroxide $\left(\mathrm{H}_{2} \mathrm{O}_{2}\right)$ that is converted by myeloperoxidase (MPO) and $\mathrm{Cl}^{-}$to the powerful twoelectron (non-radical) oxidant hypochlorous acid $(\mathrm{HOCl})$, which can chemically modify lipids, proteins and kill invading pathogens [14]. MPO-generated and exogenous $\mathrm{HOCl}$ react identically [15-17] and protein thiols and Met are preferred substrates [18]. $\mathrm{HOCl}$ also initiates LDL lipid peroxidation and formation of 3-chlorotyrosine and dityrosine [19].

A8 and S100A9 (A9), present constitutively in high concentrations $(\sim 40 \%$ of cytosolic protein) in PMN, 
may be released from activated or dying cells at inflammatory sites [1, 20,21], making them likely candidates for oxidation in acute inflammation. High levels of A8 are also released by inflammatory macrophages stimulated by IL-10 [22], suggesting that this protein has an anti-inflammatory role, possibly by scavenging $\mathrm{HOCl}$. A8 is effectively oxidized by low amounts of $\mathrm{HOCl}$ (molar ratios of $<\sim 10$ ) in vitro, with $70-80 \%$ conversion to dimer, and neutrophils activated by PMA generate an oxidative burst that efficiently oxidizes exogenous $\mathrm{A} 8$ within $10 \mathrm{~min}$, most likely via $\mathrm{H}_{2} \mathrm{O}_{2} / \mathrm{MPO}$ released by activated cells [11]. The major A8 $\mathrm{HOCl}$ oxidation products isolated by C4 RP-HPLC corresponded to $\mathrm{Cys}_{41}-\mathrm{Lys}_{34}$ and $\mathrm{Cys}_{41}-\mathrm{Lys}_{35}$ sulfinamides containing $\operatorname{Met}(\mathrm{O})$ which were formed in $\sim 80 \%$ yield [23]. Oxidation of the single Cys in $\mathrm{A} 8$ by $\mathrm{Cu}^{2+}$ to the disulfide-linked homodimer was highly specific and negated its chemotactic properties in vitro and in vivo [11] whereas the major sulfinamide form remained active [23]. Positive chemotactic activity of a $\mathrm{Cys}_{41}$ to $\mathrm{Ala}_{41}$ mutant $\left(\mathrm{Ala}_{41} \mathrm{~A} 8\right)$ confirmed that $\mathrm{Cys}_{41}$ is not essential for function, implying that covalent dimerization may structurally modify accessibility of the chemotactic hinge domain and may regulate chemotaxis in vivo. The exquisite susceptibility of A8 to oxidation, and the potentially large amounts present at sites of acute inflammation, suggests that it may also have anti-oxidant properties that protect against excessive tissue damage.

Here we further describe the oxidation products of $\mathrm{HOCl}$-oxidised A8 using peptide mapping and mass spectrometry [23]. Intra-molecular sulfinamide bonds between $\mathrm{Cys}_{41}$ and 6 of the 7 Lys residues were readily generated, as well as conversion of Met to Met-sulfoxide $[\operatorname{Met}(\mathrm{O})]$. Unusual fragmentations characteristic of sulfinamides were observed in the low energy CID and MALDI/PSD spectra of cross-linked peptides. Additional sulfinamide-containing products, corresponding to addition of Lys forming an $\varepsilon$-amino sulfinamide, were isolated when the amino acid Lys or $\alpha \mathrm{N}$-acetyl Lys was added the reaction mixture.

\section{Experimental}

\section{General}

Reagents and chemicals were analytical grade (Sigma, St. Louis, MO; BioRad, Hercules, CA) and solvents were HPLC grade (Mallinckrodt, Clayton South, Victoria, Australia). Hypochlorous acid (10-13\%) was from Aldrich (Milwaukee, WI) and quantitated spectrophotometrically as described [24]. Recombinant A8/ $\mathrm{Ala}_{41} \mathrm{~A} 8$ were produced using the pGEX expression system as detailed $[11,25,26]$. SDS/PAGE/Western blotting were performed using a Mini Protean II apparatus (BioRad, Hercules, CA) with 15\% gels and a Tris/Tricene buffer system [27]. Liquid chromatographic separations were performed using a non-metallic LC626 HPLC system (Waters, Bedford, MA) and monitored at $\mathrm{A}_{214 \mathrm{~nm}}$ and
$\mathrm{A}_{280 \mathrm{~nm}}$ with a Waters 996 photodiode array detector or $490 \mathrm{UV} /$ visible detector.

\section{Oxidation Reactions}

Oxidation of A8 with hypochlorite. A8 $(\sim 100 \mu \mathrm{g}, 10$ nmol) was diluted with PBS (100 $\mu \mathrm{l}, 25 \mathrm{mM}$ phosphate, $250 \mathrm{mM} \mathrm{NaCl}, \mathrm{pH} 7.5), \mathrm{HOCl}(5 \mu \mathrm{l}, 50 \mathrm{nmol})$, and the solution left at $22{ }^{\circ} \mathrm{C}$ for $10 \mathrm{~min}$. Products were separated using C4 RP HPLC $(5 \mu, 300 \AA, 4.6 \times 250 \mathrm{~mm}$, Vydac, Separations Group, Hesperia, CA) with a gradient of 35 to $65 \% \mathrm{CH}_{3} \mathrm{CN}, 0.1 \%$ TFA, over $30 \mathrm{~min}$. Major peaks $\left(\mathrm{A}_{214 \mathrm{~nm}}\right)$ were collected and fractions 1 and 1.1 were combined from 10 separate reactions, before partial lyophilization $(\sim 500 \mu \mathrm{l})$ and reseparation on HPLC using a gradient of 25 to $70 \% \mathrm{CH}_{3} \mathrm{CN} / 0.1 \%$ TFA over 30 $\mathrm{min}$, before analysis.

Oxidation of A8 with hypochlorite and reaction with lysine or $\mathrm{N}$-acetyl Lys. A8 $(\sim 100 \mu \mathrm{g}, 10 \mathrm{nmol})$ was diluted with PBS (100 $\mu$ l, $25 \mathrm{mM}$ phosphate, $250 \mathrm{mM} \mathrm{NaCl}, \mathrm{pH}$ 7.5), $\mathrm{HOCl}(5 \mu \mathrm{l}, 50 \mathrm{nmol})$, and the solution left at $22{ }^{\circ} \mathrm{C}$ for $\sim 20 \mathrm{~s}$, then Lys, $\alpha \mathrm{N}$-acetyl Lys, or $\varepsilon \mathrm{N}$-acetyl Lys (7.5 $\mu \mathrm{l}, 340 \mathrm{mM}$, Aldrich) was added and the solution left for $10 \mathrm{~min}$ at $22{ }^{\circ} \mathrm{C}$. Products were separated using $\mathrm{C} 4$ RP HPLC ( $5 \mu, 300 \AA, 4.6 \times 250 \mathrm{~mm}$, Vydac, Separations Group, Hesperia, CA) with a gradient of 25 to $75 \%$ $\mathrm{CH}_{3} \mathrm{CN}, 0.1 \%$ TFA, over 30 min. Major fraction $\left(\mathrm{A}_{214 \mathrm{~nm}}\right)$ were collected and lyophilised before MS analysis.

\section{Peptide Mapping}

A8 oxidation products $(100 \mu \mathrm{g})$ isolated from C4 RPHPLC were digested in ammonium bicarbonate $(400 \mu \mathrm{l}$, $50 \mathrm{mM}, \mathrm{pH}$ 8.0) using endoprotease AspN (sequencing grade, Roche, Castle Hill, NSW) at an enzyme to substrate ratio of approximately $1: 100$ at $37^{\circ} \mathrm{C}$ for $3 \mathrm{~h}$. The $\mathrm{pH}$ of the digest was adjusted to approximately 2 (TFA $1 \%$ ) and the mixture applied directly to a C18 RP-column $(5 \mu, 300 \AA$, $4.6 \times 250$ mm, Vydac, Separations Group, Hesperia, CA). Peptides were eluted with a gradient of 5 to $75 \%$ acetonitrile $(0.1 \%$ TFA) at 1 $\mathrm{ml} / \mathrm{min}$ over $30 \mathrm{~min}$. Fractions with major $\mathrm{A}_{214 \mathrm{~nm}}$ were collected, then lyophilized and redissolved in $\mathrm{H}_{2} \mathrm{O}$ / $\mathrm{CH}_{3} \mathrm{CN} /$ acetic acid (50:49:1) for ESI or MALDI MS or further enzymatic digestion.

Both isomers of oxidized $\mathrm{A}_{32-57}-\mathrm{A}_{62-83}(\sim 5 \mu \mathrm{g})$ isolated after AspN cleavage were digested with endoprotease LysC (sequencing grade, Roche) in ammonium bicarbonate ( $50 \mu \mathrm{l}, 50 \mathrm{mM}, \mathrm{pH} 8.0)$ at an enzyme to substrate ratio of approx. $1: 100$ at $37^{\circ} \mathrm{C}$ for $5 \mathrm{~h}$. Peptides were isolated using RP-HPLC as described above before ESI/MALDI MS analysis or the total digest $(1 \mu \mathrm{l})$ was analyzed by MALDI MS.

\section{Mass Spectrometry}

Electrospay ionization mass spectrometry. Masses of proteins and peptides were determined using ESI. Spectra 
were acquired using a single quadrupole mass spectrometer equipped with an ESI source (MSD1100, Hewlett Packard, Palo Alto, CA). Samples ( $\sim 50$ pmol, $10 \mu \mathrm{l})$ were injected into water:acetonitrile (50:50) $1 \%$ acetic acid (10 $\mu \mathrm{l} / \mathrm{min})$ using an LC1100 pump (HP) coupled directly to the electrospray source. Nitrogen was used as the nebulizer and drying gas $(7.0 \mathrm{~L} / \mathrm{min}$, $150{ }^{\circ} \mathrm{C}$ ). Sample droplets were ionized at a positive potential of approximately $4000 \mathrm{~V}$ and transferred to the mass analyzer with a fragmentor voltage (capillary to skimmer lens voltage) of $75 \mathrm{~V}$. Spectra were acquired over the mass range $\mathrm{m} / \mathrm{z} 200$ to 1500 in $0.5 \mathrm{~s}$ with unit resolution. Low energy CID MS/MS spectra were recorded using a triple quadrupole (TSQ 7000, Finnigan, San Jose CA) where multiply-charged $(+3,+4$, or +5$)$ precursor ions were selected with Q1, collisionally activated within rf-only Q2 (20-50 eV, argon, manifold pressure $\sim 1.5 \mathrm{mTor}$ ). Spectra recorded with unit resolution scanning Q3 over $\mathrm{m} / \mathrm{z} 50-2550$ in $2 \mathrm{~s}$ were accumulated into a single data file for 4-5 min. Ions were formed using an in house nano-ESI device. Borosilicate glass capillaries $(75 \times 1.5 \mathrm{~mm})$ were drawn to an exit i.d. of $<1 \mu \mathrm{m}$ using a micro-pipette puller (Narishige, Model PN-3, Tokyo, Japan) then tips were broken under a microscope, forming an exit i.d. of $\sim 50 \mu \mathrm{m}$. Peptide-containing solutions $\left(\sim 10 \mu \mathrm{l}, \mathrm{H}_{2} \mathrm{O} / \mathrm{CH}_{3} \mathrm{CN} /\right.$ $\left.\mathrm{CH}_{3} \mathrm{CO}_{2} \mathrm{H}, 50: 49: 1\right)$ were loaded into the capillary and electrical contact $(\sim 1-2 \mathrm{kV})$ was maintained using a gold electrode protruding into the liquid. The glass capillary was positioned $2-5 \mathrm{~mm}$ from the entrance to the heated capillary, which was at $150{ }^{\circ} \mathrm{C}$; stable ion currents were maintained with flow rates of $\sim 100-200$ $\mathrm{nl} / \mathrm{min}$.

Matrix assisted laser desorption. Peptide solutions $(\sim 25$ $\mathrm{pg} / \mu \mathrm{l})$ were mixed with matrix [1 $\mu \mathrm{l}, 2,5$ dihydroxybenzoic acid (DHB, Sigma) $10 \mathrm{mg} / \mathrm{ml}$ and air-dried before analysis. Spectra were acquired in linear mode and positive ions generated using a $\mathrm{N}_{2}$ laser $(337 \mathrm{~nm}$, 3-ns pulse width) and accelerated to $25 \mathrm{keV}$ after an extraction delay of $200 \mu$ s (Voyager STR, Perseptive Biosystems, Framingham, MA). Typically, 50 spectra were averaged and calibrated externally using angiotensin I and insulin (ox) B chain (peptides) or insulin (ox) B chain and myoglobin (proteins).

PSD were also acquired using a Voyager STR mass spectrometer, with the timed ion selector set to the precursor mass, a mirror ratio of 1.12, 11 segments with a $75 \%$ decrement ratio were acquired and stitched automatically using the instrument software (Data Explorer V3.2, Perseptive). In some experiments collision gas (air) was introduced into a collision cell located between the source and flight tube to enhance fragmentation. A different target position was chosen for each segment and $\sim 200$ spectra acquired and averaged. Spectra were calibrated using the metastable fragments of substance P or angiotensin-I (Sigma) and were generally $\pm 1.5 \mathrm{Da}$ of their predicted value for peptides $\mathrm{m} / \mathrm{z}$ $\sim 3000$ and \pm 4 for peptides $\mathrm{m} / \mathrm{z} \sim 6000$.

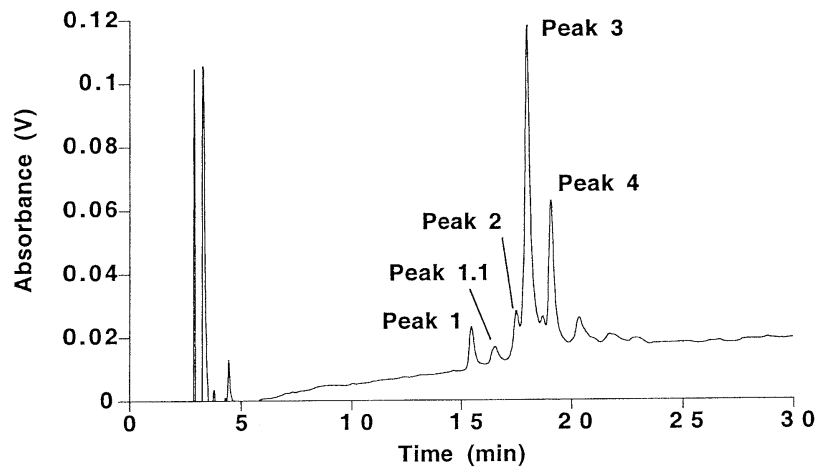

Figure 1. Preparative C4 RP-HPLC of S100A8 HOCl oxidation products. (a). Products were separated after incubation of A8 with $\sim 5$ molar equivalents of $\mathrm{HOCl}$ for $10 \mathrm{~min}$ at $22^{\circ} \mathrm{C}$. ESI masses after deconvolution were 10,354 Da (peak 1), 10,354 Da (peak 1.1), 10,388 Da (peak 2, 10,354 Da \pm 1 (peak 3), and 10,354/20,707 Da \pm 3 (peak 4).

\section{Results and Discussion}

Hypochlorite $\left(\mathrm{OCl}^{-}\right)$is the major oxidant produced by neutrophils in inflammatory responses and murine A8 is exquisitely susceptible to oxidation by $\mathrm{HOCl}[11,23]$. Low concentrations of hypochlorite $(<40 \mu \mathrm{M})$ convert A8 to a modified monomer $(10,354,+46 \mathrm{Da})$ corresponding to addition of three oxygens and loss of dihydrogen, and to oxidized dimer $(20,707,+93 \mathrm{Da})$, indicating oxidation of susceptible amino acids (Cys/ Met) and formation of intra- and inter-molecular sulfinamide cross-links [11,23]. The resistance of $\mathrm{Ala}_{41} \mathrm{~A} 8$ to $\mathrm{HOCl}-$ mediated dimerisation at all $\mathrm{HOCl}$ concentrations confirmed the role of $\mathrm{Cys}_{41}$. Reagent or MPOgenerated $\mathrm{HOCl}$ form identical reaction products in proteins [16]. Cys and Met are the preferred substrates followed by amines (e.g., Lys, forming chloramines) [18, 28]. Almost all $\alpha$ amino acids form reactive aldehydes after incubation with $\mathrm{HOCl}$ formed using the $\mathrm{MPO} /$ $\mathrm{H}_{2} \mathrm{O}_{2} / \mathrm{Cl}^{-}$system [24]. Thus, products generated by reagent $\mathrm{HOCl}$ in vitro are likely to reflect those produced by $\mathrm{HOCl}$ generated by activated phagocytes.

\section{Isolation and Characterization of $\mathrm{HOCl}$ Oxidation Products of $A 8$}

Murine A8 treated with $\sim 4-5$ equivalents of $\mathrm{HOCl}$ for $10 \mathrm{~min}$ at $20^{\circ} \mathrm{C}$ yielded 5 separate peaks after $\mathrm{C} 4$ RP-HPLC (Figure 1). The major product (Figure 1, peak 3) had a mass of $10,354 \pm 1 \mathrm{Da}$, $46 \mathrm{Da}$ greater than the unmodified protein. Three additional components of mass 10,354, 10,354, 10,388, and 10,354/20,707 (Figure 1, peaks 1, 1.1, 2, and 4) were separated and isolated using a HPLC gradient of 35 to $65 \%$ acetonitrile. We previously showed that the major product is a mixture of oxidized $\mathrm{Cys}_{41}$ covalently linked to $\mathrm{Lys}_{34 / 35}$ via the $\varepsilon$-amine forming a sulfinamide bond, and oxidation of Met to $\operatorname{Met}(\mathrm{O})$ [23]. Characterization of the novel sulfinamide oxidation product was accomplished using peptide mapping and mass spectrometry [23]. Other 

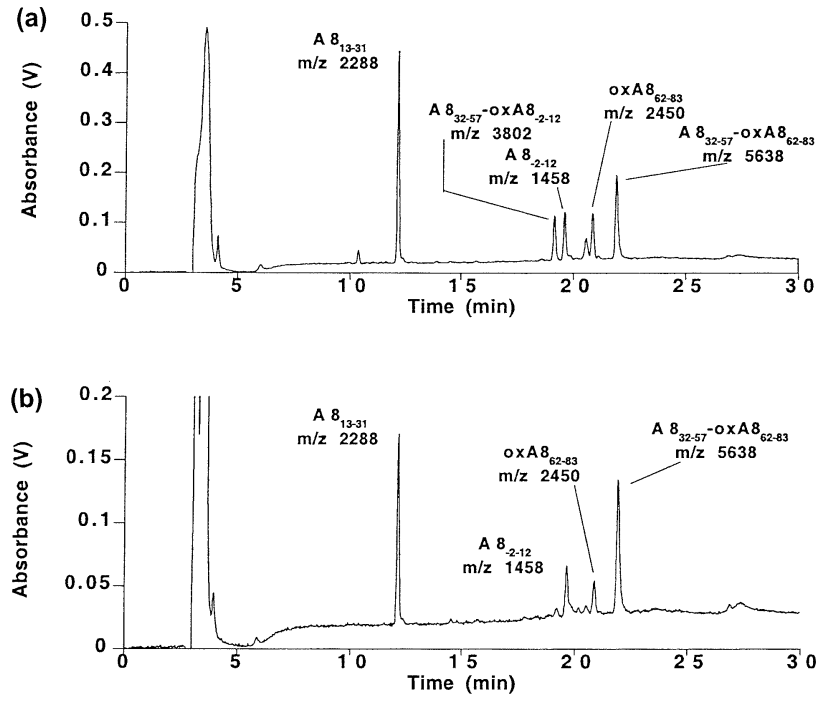

Figure 2. AspN digestion of $\mathrm{S} 100 \mathrm{~A} 8 \mathrm{HOCl}$ oxidation products [peak 1 and 1.1 (Figure 1)] separated by C18 RP-HPLC. Masses and predicted identities of digest peptides are indicted for digestion of peak 1 (a) and peak 1.1 (b). Sulfinamide cross-linked peptides have $\mathrm{m} / \mathrm{z}$ 3802, 5638 (peak 1), and 5638 (peak 1.1).

products identified in the previous study were peak 1 $\left(\mathrm{Cys}_{41}-\mathrm{Lys}_{87}\right.$ sulfinamide) peak 2 (Cys-sulfonic acid), and peak $4\left(\mathrm{Cys}_{41}-\mathrm{Lys}_{6}\right.$ sulfinamide dimer) [23]. Formation of a reactive Cys-sulfonic acid intermediate that subsequently underwent nucleophilic substitution by the $\varepsilon$-amine (from Lys) was proposed. Early publications suggest that protein sulfenic acids may undergo nucleophilic substitution with amines (e.g., benzylamine) to yield stable covalent bonds although none have been isolated or rigorously characterized [29]. Our results indicate that seven $\mathrm{A} 8$ oxidation products form after reaction of specific amino acids with a $\mathrm{Cys}(\mathrm{O})$ intermediate and that six of the seven $\varepsilon$-amines readily react with this intermediate.

The isomeric $\mathrm{HOCl}$-modified proteins (peaks 1 and 1.1, Figure 1) not fully characterized previously were digested with AspN and peptides separated by C18 RP-HPLC (Figure 2). The identities of the major digest peptides were determined based on comparisons of theoretical and experimental masses. Probable sulfinamide-containing peptides had masses of $\mathrm{m} / \mathrm{z} 3802$ and 5638. Previously, we showed that the peptide with $\mathrm{m} / \mathrm{z}$ 3802 contained a sulfinamide between $\mathrm{Cys}_{41}$ and $\mathrm{Lys}_{87}$ [23]. A peptide with an identical experimental and theoretical mass corresponding to oxidized $\mathrm{A} 8_{32-57}$ linked to $\mathrm{A}_{62-83}(\mathrm{~m} / \mathrm{z} 5638)$ via a sulfinamide was also isolated (Figure $2 \mathrm{a}$ ). This peptide ion may not have been observed in the previous study because of suppression of ionization in MALDI [30]. This indicates that peak 1 (Figure 1) is a mixture of A8 oxidation products containing sulfinamides between $\mathrm{Cys}_{41}-\mathrm{Lys}_{6}$ and $\mathrm{Cys}_{41}$ and a Lys within peptide $\mathrm{A} 8_{62-83}$. The C18 RP-HPLC chromatogram of the AspN digest of peak 1.1 shows one peak with a mass $(\mathrm{m} / \mathrm{z} 5638)$ also indicating a probable sulfinamide (Figure $2 \mathrm{~b})$. The mass $( \pm 1 \mathrm{Da})$ and reten- tion time $( \pm 10 \mathrm{~s})$ were identical to the peptide with sulfinamide between $\mathrm{Cys}_{41}$ and $\mathrm{A}_{62-83}$ isolated after AspN digestion of peak 1 (Figure 2a and b). C4 RPHPLC of peaks 1 and 1.1 revealed that each component was $>95 \%$ pure, indicating that there was little cross contamination of the 2 components and suggesting that they contain structural isomers. $\mathrm{A}_{62-83}$ has two Lys residues $\left(\mathrm{Lys}_{76}\right.$ and $\mathrm{Lys}_{83}$ ) and the precise identity of the isomers with $\mathrm{m} / \mathrm{z} 5638$ was determined after digestion of each cross-linked peptide with Lys C.

Endoprotease Lys C cleaves on the C-terminal side of Lys residues and formation of sulfinamides would likely inhibit digestion, allowing differentiation of free and covalently-linked Lys resides. Figure 3 shows the structures and masses, determined by MALDI and ESI MS, of isomeric peptides $(\mathrm{m} / \mathrm{z}$ 5638) digested with LysC (Figure $3 a$ and $b$ ) together with the digest products of $\mathrm{Cys}_{41}-\mathrm{Lys}_{6}$ sulfinamide (Figure 3c) for comparison. Digestion of sulfinamide oxA $8_{32-57}-\mathrm{oxA} 8_{62-83}$ from peak 1 gave peptides with masses of $\mathrm{m} / \mathrm{z} 5120$ and 408 which correspond to oxA $8_{37-57}-\mathrm{oxA} 8_{62-83}$ and $\mathrm{A}_{32-36}$ indicating that $\mathrm{Lys}_{76}$ was not susceptible to Lys C digestion and therefore most likely contains the sulfinamide bond between $\mathrm{Cys}_{41}$ and $\mathrm{Lys}_{76}$. In comparison, digestion of sulfinamide oxA $8_{32-57}-\mathrm{OxA} 8_{62-83}$ from peak 1.1 yielded peptides with masses of $\mathrm{m} / \mathrm{z} 3385,1770$ and 408 which correspond to sulfinamide $\mathrm{A}_{37-57^{-}}$ oxA $8_{77-83}, \mathrm{oxA}_{62-76}$ and $\mathrm{A} 8_{32-36}$ indicating that $\mathrm{Lys}_{76}$ was susceptible to Lys $C$ digestion and therefore the most likely sulfinamide bond would be between $\mathrm{Cys}_{41}$ and $\mathrm{Lys}_{83}$. The expected Lys C digest products of $\mathrm{Cys}_{41}{ }^{-}$ Lys $_{6}$ are $\mathrm{m} / \mathrm{z} 3285$ and 408 corresponding to sulfinamide oxA $8_{37-57}-\mathrm{A} 8_{-2-12}$ and are identical to the predicted masses of digestion of this peptide (Figure 3c).

Peak 4 (Figure 1) contains sulfinamide-bonded dimer of A8, with sulfinamide bonds between $\mathrm{Cys}_{41}$ and $\mathrm{Lys}_{6}$ and $\mathrm{Cys}_{41}$ and $\mathrm{Lys}_{34 / 35}$ [23]. This peak also contained a variable proportion of monomer (up to $\sim 50 \%$ ) (mass $10,354 \mathrm{Da}$ ) that was not resolved from the dimer using C4 RP HPLC. A sulfinamide cross-linked peptide (oxA $8_{32-57}-\mathrm{A} 8_{-2-12}$ ) of mass $\mathrm{m} / \mathrm{z} 4647$ was isolated from peak 4 (Figure 1) after AspN digestion and C18 RPHPLC and was also used in the MS structural studies. The amino acid sequence of $A 8$, together with the sequence and position of modified Cys and Lys residues and the structures of the major $\mathrm{HOCl}$ oxidation products of A8, are shown in Figure 4.

Interestingly, sulfinamide bonds in the cross-linked peptides appeared stable at $\mathrm{pH}>7$ for extended times ( $>7$ days), whereas the bond was hydrolysed within a few days storage at $\mathrm{pH} \sim 2.5\left(4^{\circ} \mathrm{C}\right)$ forming a peptide containing Cys-sulfinic acid $\left(\mathrm{CysSO}_{2} \mathrm{H}\right)$ and a peptide with unmodified Lys. These products were readily separated by RP-HPLC and masses determined by ESI (not shown). A possible hydrolysis mechanism is outlined in Scheme $\mathbf{1}$ and is similar to acid-catalysed hydrolysis of ester/amide bonds [31]. Protein containing sulfinamides were stable at $\mathrm{pH} \sim 2$ for $>6$ months at $-80^{\circ} \mathrm{C}$. 
(a)

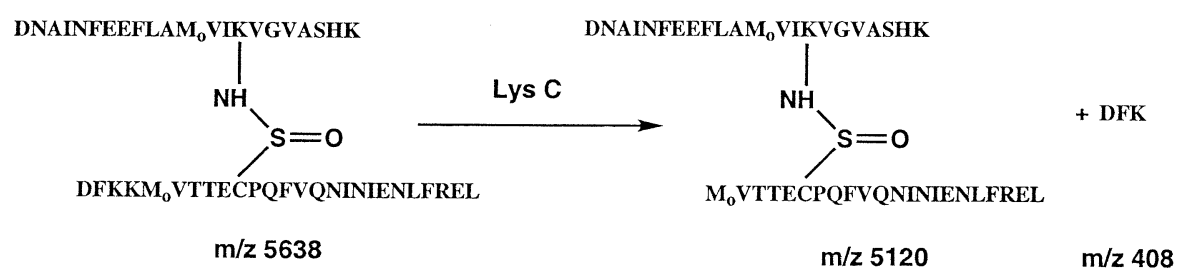

(b)

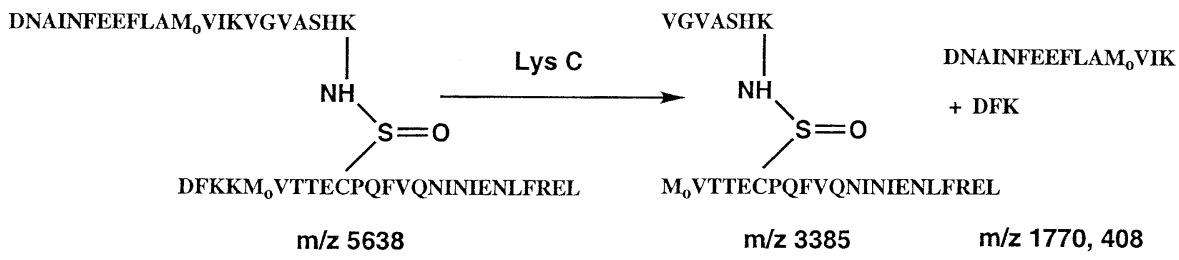

(c) DSH

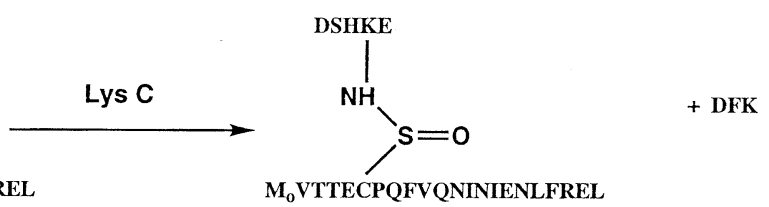

$\mathrm{m} / \mathrm{z} 3802$

$\mathrm{m} / \mathrm{z} 3285$

$\mathrm{m} / \mathrm{z} 408$

Figure 3. Products of endoprotease Lys C digestion of sulfinamide cross-linked peptides $\mathrm{m} / \mathrm{z} 5638$ and 3802. The specific Lys residues on isomeric peptides $(\mathrm{m} / \mathrm{z} 5638)$ derived from AspN digestion of peaks 1 (a) and 1.1 (b) were determined after digestion with endoprotease LysC because sulfinamidelinked Lys resides were resistant to protease digestion.

\section{Low Energy Collision Induced Dissociation of Multiply-Charged Sulfinamide Containing Peptides}

Four sulfinamide cross-linked peptides were analyzed by ESI low energy CID tandem MS isolated after Asp N digestion and C18 RP-HPLC of peaks 1, 1.1, and 4 . These corresponded to oxidized $\mathrm{A} 8_{37-57}-\mathrm{A}_{84-88}(\mathrm{~m} / \mathrm{z}$ 3802, $\mathrm{Cys}_{41}-\mathrm{Lys}_{87}$ sulfinamide), $\mathrm{A} 8_{37-57}-\mathrm{A}_{62-83}(\mathrm{~m} / \mathrm{z}$ 5638, $\mathrm{Cys}_{41}-\mathrm{Lys}_{76}$ sulfinamide), $\mathrm{A} 8_{37-57}-\mathrm{A} 8_{62-83}(\mathrm{~m} / \mathrm{z}$ 5638, $\mathrm{Cys}_{41}-\mathrm{Lys}_{83}$ sulfinamide), and $\mathrm{A} 8_{37-57}-\mathrm{A} 8_{-2-12}$ $\left(\mathrm{m} / \mathrm{z}\right.$ 4647, $\mathrm{Cys}_{41}-\mathrm{Lys}_{6}$ sulfinamide). The most intense multiply-charged ion for each peptide was selected with MS1 and a collision energy chosen that showed the most intense product ions (Figure 5a, b, c, d). The collision gas pressure was constant for all MS/MS spectra at $\sim 1.5$ mTorr Ar. MS/MS CID spectra of each multiply-charged ion contained very similar fragmentation patterns for all the sulfinamide cross-linked peptides. Two sets of intense multiply charged product ions that corresponded to protonated peptides derived after cleavage of the nitrogen sulfur sulfinamide bond, with charge retention on either fragment were generally observed. These products are similar to those expected after $y$ - or b-type cleavage of peptide bonds after CID and are designated $\mathrm{F}_{\mathrm{N}}$ (charge retention on Lys containing peptide) and $F_{S}$ (charge retention on Cys containing peptide) fragment ions in Figure $5 . \mathrm{F}_{\mathrm{N}}$ fragment ions have experimental masses corresponding to theoretical masses of protonated peptides containing no modifications $(\mathrm{m} / \mathrm{z} \pm 0.5)$. The theoretical average mass of the $[\mathrm{M}+\mathrm{H}]^{+}$ion $\left(\mathrm{F}_{\mathrm{S}}\right.$ fragments Figure 5) formed after simple cleavage of the sulfinamide bond was $\mathrm{m} / \mathrm{z}$ 3187.7. The average experimental mass, derived from the multiply charged fragment ions, is $\mathrm{m} / \mathrm{z} 3188$ $( \pm 0.6)$. Charge remote fragmentation mechanism have been proposed for elimination reactions of protonated peptides containing alkylated oxidized Cys resides after low energy CID with a Q-star mass spectrometer [32]. More accurate products ion mass measurement using a Q-TOF or MS $^{3}$ (ion trap) may resolve the precise mechanism and the products formed during low energy CID of sulfinamide bonded peptides. Additional ions, some corresponding to the expected sequence ions of both peptides were also observed and were enhanced by increasing the collision energy by $50-100 \%$ (not shown).

\section{MALDI-Post Source Decay Analysis of Protonated Sulfinamide Containing Peptides}

The four sulfinamide cross-linked peptides from C18 RP-HPLC were analyzed by MALDI/PSD using DHB 
(a) -2GSPSELEK"ALSNLIDVYHNYSNIQGNHHALYK ${ }^{30}$ ${ }^{3}{ }^{N D F K}{ }^{\#} K^{\#} M^{*} V T T E C^{* \# P Q F V Q N I N I E N L F R E L D I N ~}{ }^{\circ 0}$ ${ }^{61}$ SDNAINFEEFLAM ${ }^{*}$ IKV $^{\#}$ GVASHK $^{\#}$ DSHK $^{\#}{ }^{88}$

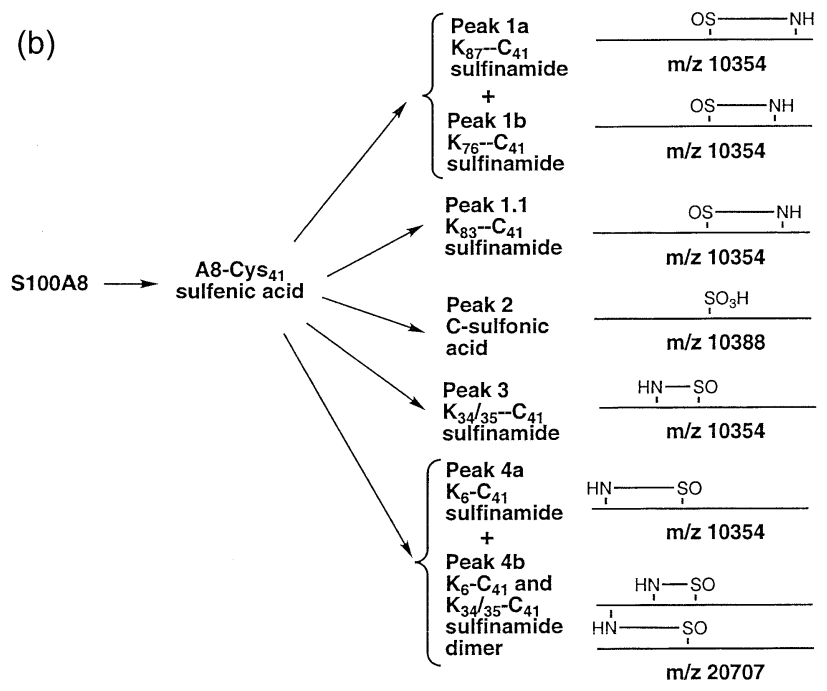

Figure 4. Structures of sulfinamide cross-linked S100A8. (a) A8 amino acid sequence indicating locations of Lys, Met, and Cys residues modified by $\mathrm{HOCl}$ oxidation (labeled with a pound sign or an asterisk). Six of the seven Lys resides in S100A8 formed sulfinamide cross-links with the reactive intermediate $\mathrm{Cys}_{41}$ sulfenic acid. (b) Proposed structures of $\mathrm{Cys}_{41}-\mathrm{Lys}_{X}$ sulfinamidebonded products identified after oxidation of $\mathrm{A} 8$ with $\mathrm{HOCl}$. The structures of the major products (peaks 2, 3, and 4) were determined in a previous study [23].

matrix (Figure 6a, b, c, d) after selecting the precursor ion using the timed ion selector. Apart from an increase in the intensities of low-mass immonium ions, identical spectra were obtained employing CID (not shown). Mass accuracy of product ions were generally within $\mathrm{m} / \mathrm{z} \pm 1.5$ of theoretical values for precursor ions at $\sim 3000$ and $\mathrm{m} / \mathrm{z} \sim \pm 4$ for precursor ions at $\sim 6000$. Although product ion mass accuracy was modest, fragmentations of sulfinamides, which were only evident by MALDI, were observed and are probably highenergy or photo-dissociation processes not normally observed in low energy CID MS/MS spectra using triple quadrupoles. Fragmentation of the sulfinamide bond forming two protonated product ions, similar to those observed in the ESI/MS/MS spectra, were also

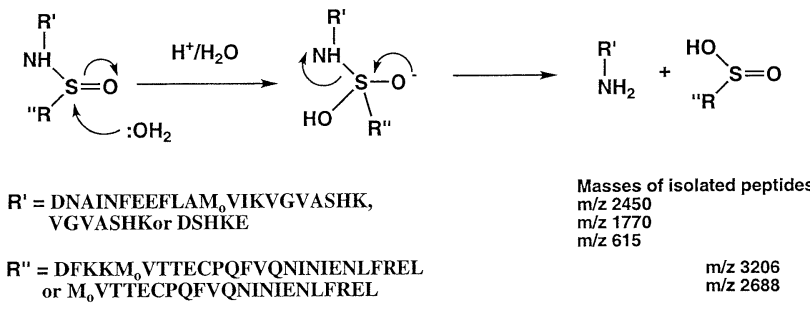

Scheme 1 Acid catalysed hydrolysis of sulfinamide cross-linked peptides forms Cys-sulfinic acid and Lys containing peptides. evident in the PDS spectra (i.e., ions at $m / z \sim 3190$ in Figure $6 \mathrm{a}, \mathrm{b}, \mathrm{c}, \mathrm{d}$ and 2449 in b and c). However additional fragmentations characteristic of sulfinamides and $\operatorname{Met}(\mathrm{O})$ that corresponded to elimination reactions forming dehydro-alanine were also observed. Eliminations of this type in CID MS/MS spectra were recently reported for alkylated oxidized Cys residues [32] and $\operatorname{Met}(\mathrm{O})$ readily eliminates methanesulfenic acid [33]. Scheme 2 proposes a similar charge remote fragmentation mechanism to account for the formation of a protonated peptide containing dehydro-alanine after CID of protonated sulfinamides. Loss of $m / z \sim 64$ from the precursor ion, and from other major ions, corresponds to the loss of methansulfenic acid from $\operatorname{Met}(\mathrm{O})$ would occur as described [32, 33]. More accurate product ion mass measure, possibly using high energy CID with a TOF-TOF MS, would allow products ions and fragmentation mechanism to be more precisely defined [34]. The ion at $m / z \sim 1974$ in all PSD spectra corresponds to the sequence $\mathrm{A}_{42-57}$ (PQFVQNINIENLFREL) formed after y-type peptide bond cleavage of the $\mathrm{Cys}_{41}-\mathrm{Pro}_{42}$ bond of the precursor ion.

\section{Low Energy CID/MALDI PSD Analysis of A8-Lys Sulfinamide Adduct}

The reactivity of the initially-formed A8-Cys sulfenic acid was tested by addition of lysine, $\alpha \mathrm{N}$-acetyl lysine or $\varepsilon \mathrm{N}$-acetyl lysine to the reaction mixture. The $\mathrm{C} 4$ RP-HPLC chromatograms were virtually unchanged except for a minor peak eluting as a partially resolved shoulder before peak 2 (Figure 1) after addition of Lys, which was isolated (not shown). The mass of this adduct was $10,500 \mathrm{Da}$ and corresponds to the theoretical mass $(10,499.5 \mathrm{Da})$ of Met-oxidized A8 covalently linked to Lys via a sulfinamide bond. No additional adducts were isolated after addition of $\varepsilon \mathrm{N}$-acetyl Lys, but an adduct with $10542 \mathrm{Da}$ was isolated after incubation with $\alpha \mathrm{N}$-acetyl Lys, corresponding to $\varepsilon$-substituted A8 $\alpha \mathrm{N}$-acetyl Lys sulfinamide (theoretical mass $10542 \mathrm{Da})$, indicating preferential substitution of the $\varepsilon$-amine versus $\alpha$-amine of Lys. The most likely protein containing sulfinamides would also be via the $\varepsilon$-amine of Lys.

Digestion of the A8-Lys sulfinamide adduct with AspN and separation by C18 RP-HPLC revealed the expected A8 digest peptides together with a peptide corresponding to $\mathrm{A} 8_{32-57}$-Lys sulfinamide $(\mathrm{m} / \mathrm{z} 3336)$ (not shown). Fragmentations consistent with a $\mathrm{Cys}_{41}{ }^{-}$ Lys sulfinamide were identified using ESI low energy CID MS/MS and MALDI PSD analysis of isolated peptides. Electrospray low energy CID MS/MS spectra of $[\mathrm{M}+4 \mathrm{H}]^{4+}$ and $[\mathrm{M}+3 \mathrm{H}]^{3+}$ precursor ions of $\mathrm{A} 8_{32-57}$-Lys sulfinamide are shown in Figure $7 \mathrm{a}$ and $\mathrm{b}$. Similar to the fragmentations observed in the spectra of the sulfinamide cross-linked peptides (Figure 5), the major fragmentation in both spectra is cleavage of the sulfinamide bond forming protonted Lys $(\mathrm{m} / \mathrm{z} 147)$ and 


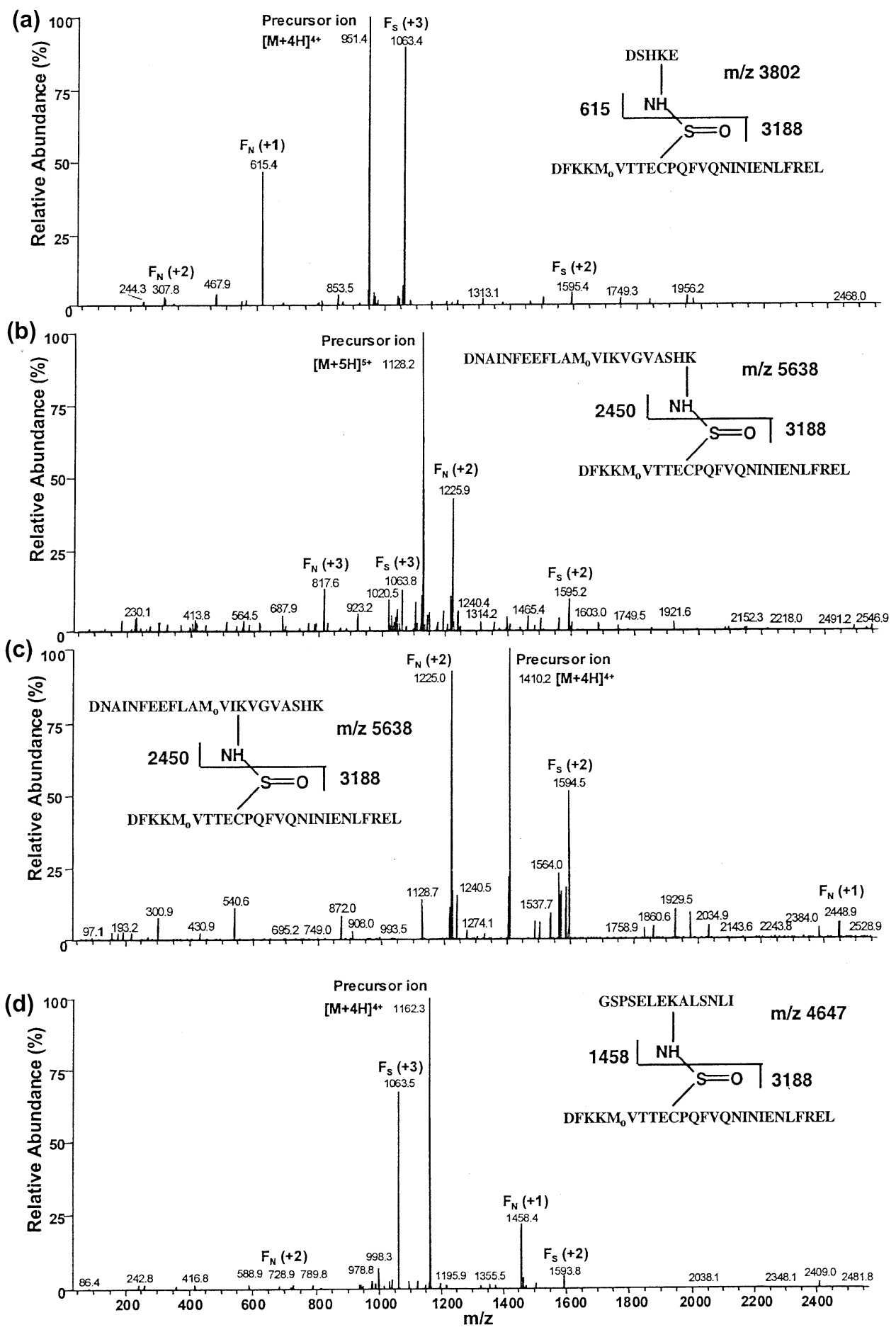

Figure 5. Low energy CID MS/MS spectra of protonated sulfinamide containing peptides. Collisional activation of multiply-charged sulfinamide cross-linked peptides caused simple cleavage of the nitrogen-sulfur bond forming two peptide fragments which share the charges originally located on the precursor ion. Precursor ions are indicated together with major fragment ions, these are designated $\mathrm{F}_{\mathrm{N}}$ or $\mathrm{F}_{\mathrm{S}}$ and charge states are shown in parenthesis (the insert in each spectrum shows the structure of precursor ion and experimentally derived $\mathrm{m} / \mathrm{z}$ of singly protonated precursor and product ions). (a) $[\mathrm{M}+4 \mathrm{H}]^{4+}$ ion $\left(\mathrm{m} / z\right.$ 951.4) of $\mathrm{A}_{32-57}-\mathrm{A} 8_{84-88}\left(\mathrm{Cys}_{41}-\mathrm{Lys}_{87}\right.$ sulfinamide) was fragmented at $25 \mathrm{eV}$, forming major product ions at $\mathrm{m} / \mathrm{z} 1063.4$ and 615.4; similarly, $(\mathbf{b})[\mathrm{M}+5 \mathrm{H}]^{5+}$ ion $(\mathrm{m} / \mathrm{z} 1128.2)$ of $\mathrm{A} 8_{32-57}-\mathrm{OxA}_{62-83}\left(\mathrm{Cys}_{41}-\mathrm{Lys}_{83}\right.$ sulfinamide) was fragmented at $40 \mathrm{eV}$, forming major product ions at $\mathrm{m} / z$ 1595.2, 1063.4, 1225.9, and 817.6; (c) $[\mathrm{M}+4 \mathrm{H}]^{4+}$ ion $(\mathrm{m} / \mathrm{z} 1410.2)$ of $\mathrm{A} 8_{32-57}-\mathrm{oxA}_{62-83}\left(\mathrm{Lys}_{76}-\mathrm{Cys}_{41}\right.$ sulfinamide) was fragmented at $50 \mathrm{eV}$, forming major product ions at $\mathrm{m} / \mathrm{z} 1594.5$ and 1225.0; and (d) $[\mathrm{M}+4 \mathrm{H}]^{4+}$ ion $(m / z 1162.3)$ of $\mathrm{A} 8_{-2-12}-\mathrm{A} 8_{32-57}\left(\mathrm{Cys}_{41}-\mathrm{Lys}_{6}\right.$ sulfinamide) was fragmented at $50 \mathrm{eV}$, forming major product ions at $\mathrm{m} / \mathrm{z} 1063.5$ and 1458.4 . 

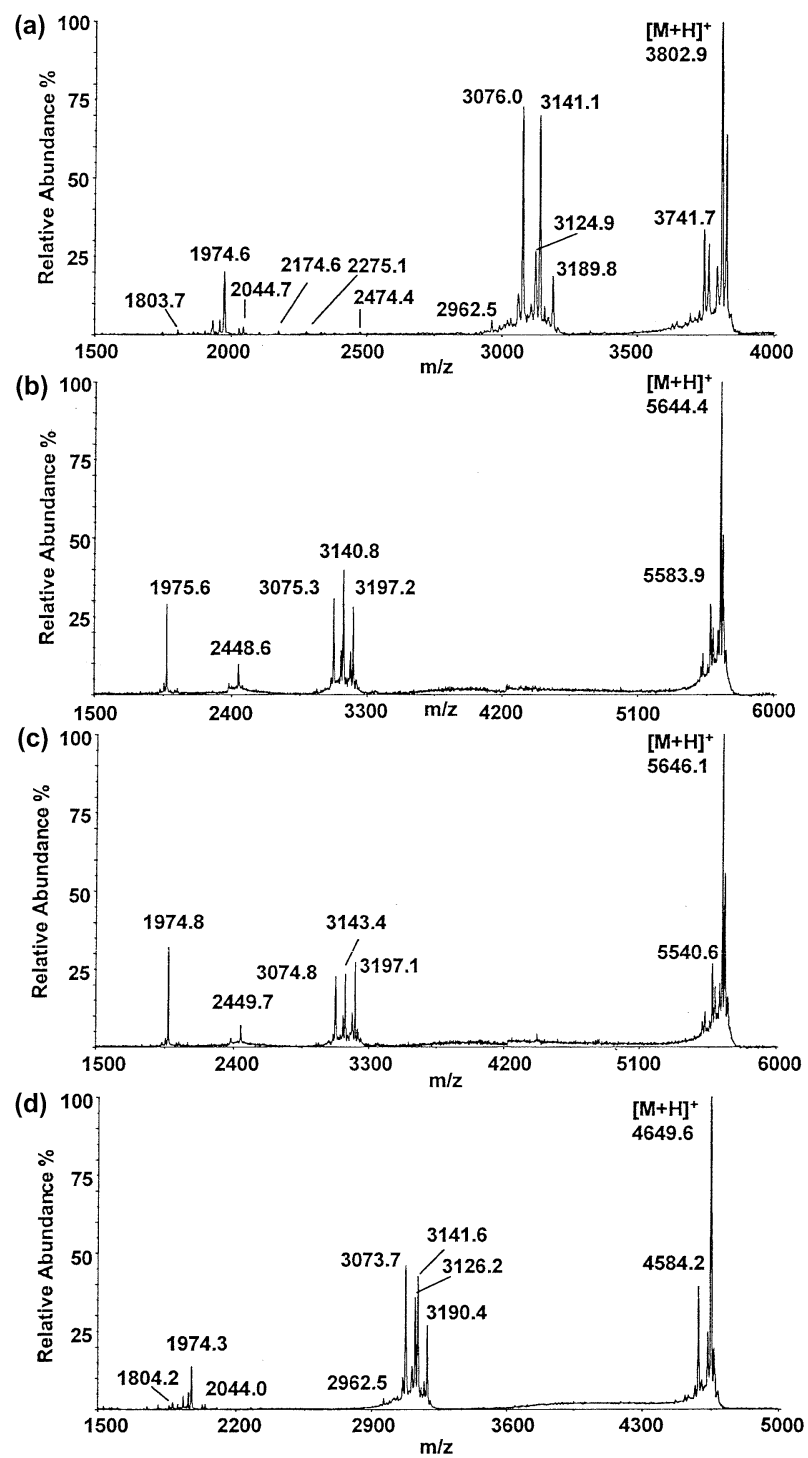

Figure 6. MALDI/PSD spectra of protonated sulfinamide containing peptides. Singly protonated sulfinamide cross-linked peptides all fragment similarly, by fragmentation of the sulfinamide bond (similar to those observed in the low energy CID spectra). Major losses corresponding to fragmentation of sulfur methylene bond, forming protonated peptides containing dehydroalanine also occur (see Scheme 2). Intense losses of methanesulfenic acid $[\mathrm{m} / \mathrm{z} 64$ from $\operatorname{Met}(\mathrm{O})]$ are also evident, as is $\mathrm{y}^{\prime \prime}{ }_{16}$ forming the ion at $m / z$ 1975. (a) $\mathrm{A} 8_{32-57}-\mathrm{A} 8_{84-88}\left(\mathrm{Cys}_{41}-\mathrm{Lys}_{87}\right.$ sulfinamide) $\mathrm{m} / \mathrm{z} 3802$; (b) $\mathrm{A} 8_{32-57}-\mathrm{oxA}_{62-83}\left(\mathrm{Cys}_{41}-\mathrm{Lys}_{83}\right.$ sulfinamide); (c) $\mathrm{A}_{32-57}$ oxA8 $_{62-83}\left(\mathrm{Cys}_{41}-\mathrm{Lys}_{76}\right.$ sulfinamide); (d) $\mathrm{A} 8_{32-57}-\mathrm{A} 8_{-2-12}\left(\mathrm{Lys}_{6}-\right.$ $\mathrm{Cys}_{41}$ sulfinamide).

a protonated peptide with $\mathrm{m} / \mathrm{z}$ 3188. Some additional ions corresponding to peptide bond cleavages of protonated oxA $8_{32-57}$ are also evident at higher collision energies (not shown). Fragmentations in the MALDI PSD spectra were also consistent with $\mathrm{A} 8_{32-57}-\mathrm{Lys}$ sulfinamide (Figure 7c). Major losses forming protonated dehydroalanine ${ }_{41}-\mathrm{oxA}_{32-57}(\mathrm{~m} / \mathrm{z} 3139)$ with subsequent loss of methanesulfenic acid $(\mathrm{m} / \mathrm{z}$ 3077.4) were the most intense peaks observed. Loss of methanesulfenic acid from the precursor the ion at $\mathrm{m} / \mathrm{z} 3273.1$

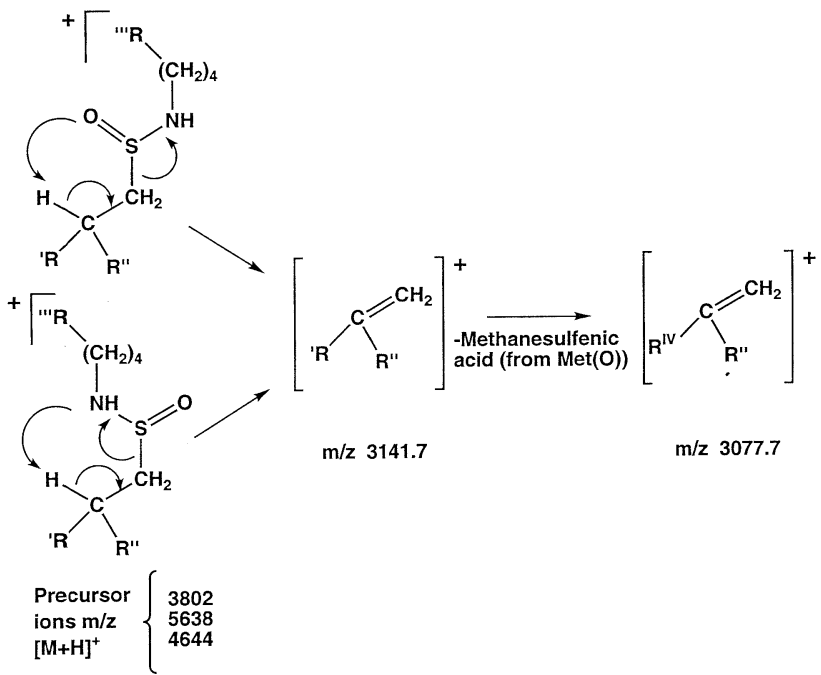

Scheme 2 Proposed structures and fragmentation mechanism of $\mathrm{Cys}_{41}$-Lys sulfinamide cross-linked peptides forming de-hydroalanine containing peptides by MALDI-PSD.

was evident. Peptide bond fragmentations (y-type) are also shown; $\mathrm{y}_{17-19,21}$ indicate the presence of dehydroalanine, suggesting that formation of this product ion is very favorable in MALDI (high energy) processes.

\section{Conclusions}

Sulfinamide bond formation is a novel oxidative crosslinking process resulting in covalent bonds between thiols and amines, which may stabilise/modify protein function and would be resistant to regeneration by conventional pathways involving reductases. In the inflammatory milieu, sulfinamide bond formation between Lys and Cys residues in proteins, or S100 crosslinking with other proteins, could potentially regulate normal and pathological processes. $\mathrm{HOCl}$ generated by activated macrophages in inflammatory lesions modifies Apo B 100 in LDL without significant lipid oxidation. Apo B becomes aggregated and cross-linked, with loss of amines producing a high uptake form that accelerates foam cell formation in atherosclerosis [16]. The protein may be cross-linked/aggregated by sulfinamide bonds. Further experiments are required to define the generality of this oxidative modification and its importance in regulating protein function and disease processes, particularly relevant to aging, atherogenesis, fibrosis, and neurogenerative diseases. The sensitivity and specificity of mass spectrometry will allow characterization of sulfinamides isolated from inflammatory lesions, or from normal tissue, where they may form only at low levels.

\section{Acknowledgments}

This work was supported in part by grants from the National Health and Medical Research Council of Australia and The Australian Research Council. The authors acknowledge members of the Cytokine Research Unit for helpful discussions. The authors 

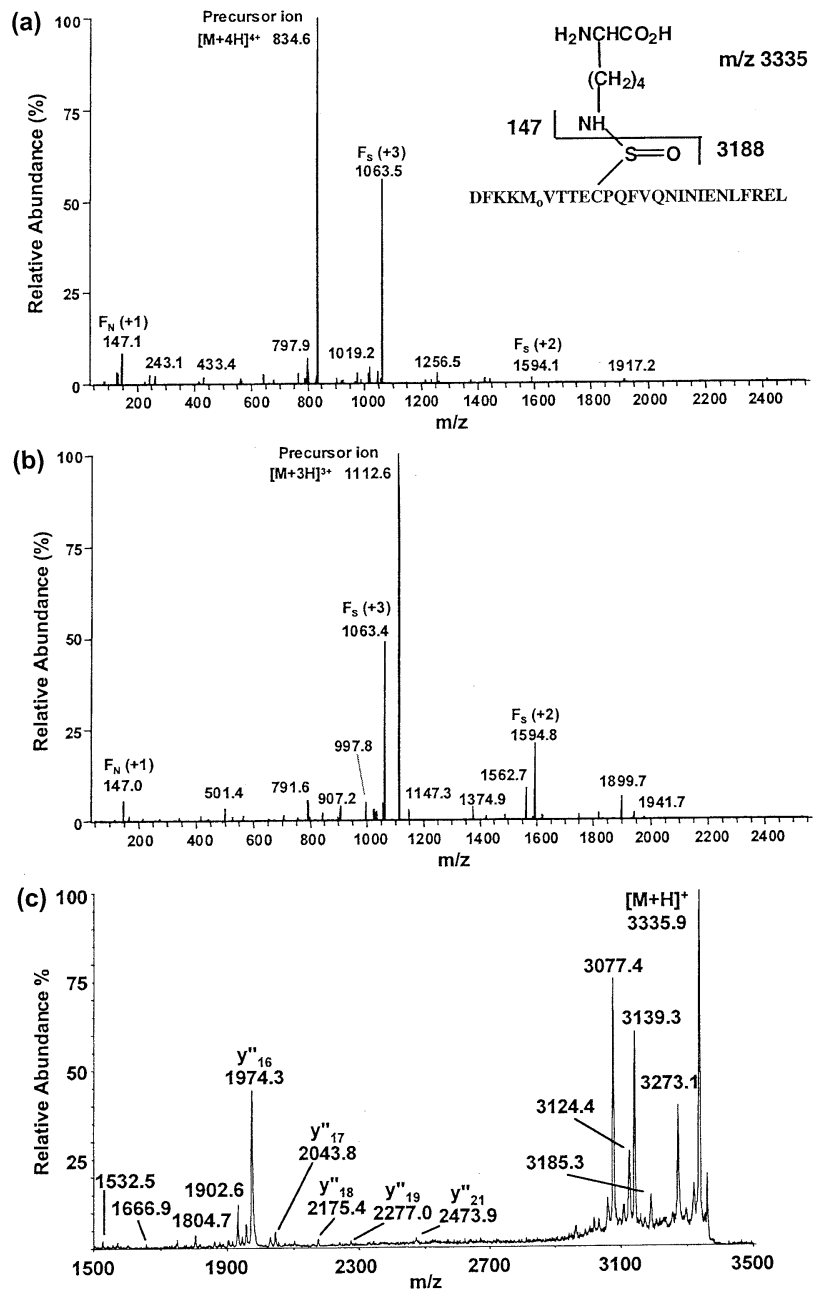

Figure 7. ESI low energy CID MS/MS and MALDI/PSD spectra of protonated $\mathrm{A}_{32-57} \mathrm{Cys}_{41}$-Lys sulfinamide derivative. $\mathrm{A} 8_{32-57}$ $\mathrm{Cys}_{41}$-Lys sulfinamide $(\mathrm{m} / \mathrm{z}$ 3336) isolated by C18 RP-HPLC after AspN digestion of the $\mathrm{S} 100 \mathrm{~A} 8_{32-57}$-Lys sulfinamide derivative (mass $10500 \mathrm{Da})$. (a) ESI MS/MS spectrum $(40 \mathrm{eV})$ of $[\mathrm{M}+4 \mathrm{H}]^{4+}$ ion $\left(\mathrm{m} / \mathrm{z}\right.$ 834.6) of $\mathrm{A}_{32-57}-\mathrm{Lys}\left(\mathrm{Cys}_{41}\right.$-Lys sulfinamide) with formation of multiply charged $\mathrm{A} 8_{32-57}$ ions (designated $\mathrm{F}_{\mathrm{S}}$ ions, $\mathrm{m} / \mathrm{z}$ $1063.5+3$ charge state, $1594.1+2$ charge state) and protonated Lys $\left(\mathrm{F}_{\mathrm{N}}\right.$ ion, $\mathrm{m} / \mathrm{z}$ 147). The insert shows the structure of the precursor ion and experimentally derived $\mathrm{m} / \mathrm{z}$ of singly protonated product ions); (b) similar fragmentations and product ions are observed after $\mathrm{CID}(50 \mathrm{eV})$ of the $[\mathrm{M}+3 \mathrm{H}]^{3+}$ ion $(\mathrm{m} / \mathrm{z} 1112.6)$ of $\mathrm{A} 8_{32-57}-\mathrm{Lys}$ sulfinamide. (c) MALDI/PSD spectrum of $\mathrm{A}_{32-57} \mathrm{Cys}_{41}-\mathrm{Lys}$ sulfinamide. Formation of protonated dehydroalanine ${ }_{41} \mathrm{~A} 8_{32-57}$ $(\mathrm{m} / \mathrm{z} 3139)$ followed by loss of methansulfenic acid $(\mathrm{m} / \mathrm{z} 3077)$ are evident. Additional sequence-specific y-type ions are also indicated in $\mathrm{C}$.

are grateful to Professor Peter Barry (Physiology and Pharmacology, UNSW) for the loan of the capillary puller and the Ray Williams Biomedical Mass Spectrometry Facility (Faculty of Medicine, UNSW) for access to the mass spectrometers are thanked.

\section{References}

1. Hessian, P. A.; Edgeworth, J.; Hogg, N. MRP-8 and MRP-14, Two Abundant $\mathrm{Ca}(2+)$-Binding Proteins of Neutrophils and Monocytes. J. Leukoc. Biol. 1993, 53, 197-204.
2. Fano, G.; Biocca, S.; Fulle, S.; Mariggio, M. A.; Belia, S. The A-100-A Protein Family in Search of a Function. Prog. Neurobiol. 1995, 46, 71-82.

3. Schäfer, B. W.; Heizmann, C. W. The S100 Family of EF-Hand Calcium-Binding Proteins: Functions and Pathology. TIBS 1996, 21, 134-140.

4. Passey, R. J.; Xu, K.; Hume, D. A.; Geczy, C. L. S100A8: Emerging Functions and Regulation. J. Leukoc. Biol. 1999, 66, 549-556.

5. Donato, R. Functional Roles of S100 Proteins, Calcium-Binding Proteins of the EF-Hand Type. Biochim. Biophys. Acta 1999, 1450, 191-231.

6. Lackmann, M.; Cornish, C. J.; Simpson, R. J.; Moritz, R. L.; Geczy, C. L. Purification and Structural Analysis of a Murine Chemotactic Cytokine (CP-10) with Sequence Homology to S-100 Proteins. J. Biol. Chem. 1992, 267, 7499-7504.

7. Harrison, C. A.; Raftery, M. J.; Alewood, P. F.; Geczy, C. L. Structure/Function Studies of S100A8/A9. Lett. Peptide Sci. 2000, 6, 359-369.

8. Raftery, M. J.; Geczy, C. L. Identification of Noncovalent Dimeric Complexes of the Recombinant Murine S100 Protein CP10 by Electrospray Ionization Mass Spectrometry and Chemical Cross-Linking. J. Am. Soc. Mass Spectrom. 1998, 9, 533-539.

9. Kligman, D.; Hilt, D. C. The S100 Protein Family. TIBS 1988, $13,437-443$.

10. Scotto, C.; Mely, Y.; Ohshima, H.; Garin, J.; Cochet, C.; Chambaz, E.; Baudier, J. Cysteine Oxidation in the Mitogenic S100B Protein Leads to Changes in Phosphorylation by Catalytic CKII- $\alpha$ Subunit. J. Biol. Chem. 1998, 273, 3901-3908.

11. Harrison, C. A.; Raftery, M. J.; Walsh, J.; Alewood, P.; Iismaa, S. E.; Thliveris, S.; Geczy, C. L. Oxidation Regulates the Inflammatory Properties of the Murine S100 Protein S100A8. J. Biol. Chem. 1999, 274, 8561-8569.

12. Deshpande, R.; Woods, T. L.; Fu, J.; Zhang, T.; Stoll, S. W.; Elder, J. T. Biochemical Characterization of S100A2 in Human Keratinocytes: Subcellular Localization, Dimerization, and Oxidative Cross-Linking. J. Invest. Dermatol. 2000, 115, 477485.

13. Weiss, S. J. Tissue Destruction by Neutrophils. N. Engl. J. Med. 1989, 320, 365-376.

14. Winterbourn, C. C.; Kettle, A. J. Biomarkers of Myeloperoxidase-Derived Hypochlorous Acid. Free Radic. Biol. Med. 2000, 29, 403-409.

15. Drozdz, R.; Naskalski, J. W.; Sznajd, J. Oxidation of Amino Acids and Peptides in Reaction with Myeloperoxidase, Chloride, and Hydrogen Peroxidase. Biochim. Biophys. Acta 1988, 957, 47-52.

16. Hazell, L. J.; van der Berg, J. J. M.; Stocker, R. Oxidative Aggregation of Isolated LDL with Hypochlorite Involves Lysine Residues but not Lipid Oxidation. Biochem. J. 1994, 302, 297-304.

17. Anderson, M. M.; Requena, J. R.; Crowley, J. R.; Thorpe, S. R.; Heinecke, J. W. The Myeloperoxidase System of Human Phagocytes Generates $\mathrm{N}^{\varepsilon}$-(Carboxymethyl)Lysine on Proteins: A Mechanism for Producing Advanced Glycation End Products at Sites of Inflammation. J. Clin. Invest. 1999, 104, 103-113.

18. Winterbourn, C. C. Comparative Reactivities of Various Biological Compounds with Myeloperoxidase-Hydrogen PeroxideChloride, and Similarity of the Oxidant to Hypochlorite. Biochim. Biophys. Acta 1985, 840, 204-10.

19. Hazen, S. L.; Heinecke, J. W. 3-Chlorotyrosine, a Specific Marker of Myeloperoxidase-Catalysed Oxidation, is Markedly Elevated in Low Density Lipoprotein Isolated from Human Atherosclerotic Intima. J. Clin. Invest. 1997, 99, 2075-2081. 
20. Kerkhoff, C.; Klempt, M.; Sorg, C. Novel Insights into Structure and Function of MRP8 (S100A8) and MRP14 (S100A9). Biochim. Biophys. Acta 1998, 1448, 200-211.

21. Hetland, G.; Talgö, G. J.; Fagerhol, M. K. Chemotaxins C5a and fMLP Induce Release of Calprotectin (Leucocyte L1 Protein) from Polymorphonuclear Cells in Vitro. Mol. Pathol. 1998, 51, 143-148.

22. Xu, K.; Yen, T.; Geczy, C. Il-10 Up-Regulates Macrophage Expression of the S100 Protein S100A8. J. Immunol. 2001, 166, 6358-66.

23. Raftery, M. J.; Yang, Z.; Valenzuela, S. M.; Geczy, C. L. Novel Intra- and Inter-Molecular Sulfinamide Bonds in S100A8 Produced by Hypochlorite Oxidation. J. Biol. Chem. 2001, 276, 33393-33401.

24. Hazen, S. L.; Hsu, F. F. ; d'Avignon, A.; Heinecke, J. W. Human Neutrophils Employ Myeloperoxidase to Convert $\alpha$ Amino Acids to a Battery of Reactive Aldehydes: A Pathway for Aldehyde Generation at Sites of Inflammation. Biochem. 1998, 37, 6864-6873.

25. Iismaa, S. E.; Hu, S. P.; Kocher, M.; Lackmann, M.; Harrison, C. A.; Thliveris, S.; Geczy, C. L. Recombinant and Cellular Expression of the Murine Chemotactic Protein, CP-10. DNA Cell Biol. 1994, 13, 183-192.

26. Raftery, M. J.; Harrison, C. H.; Geczy, C. L. Characterization of a Mutant Recombinant S100 Protein Using Electrospray Ionization Mass Spectrometry. Rapid Commun. Mass Spectrom. 1997, 11, 405-409.
27. Schägger, H. von; Jagow, G. Tricine-Sodium Dodecyl Sulphate-Polyacrylamide Electrophoresis for the Separation of Peptides in the Range 1 to $100 \mathrm{kDa}$. Anal. Biochem. 1987, 166, 368-379.

28. Carr, A. C.; Tijerina, T.; Balz, F. Vitamin C Protects Against and Reverses Specific Hypochlorous Acid and ChloramineDependent Modifications of Low-Density Lipoprotein. Biochem. J. 2000, 346, 491-499.

29. Allison, W. S. Formation and Reactions of Sulfenic Acids in Proteins. Acc. Chem. Res. 1976, 9, 293-299.

30. Wang, M. Z.; Fitzgerald, M. C. A Solid Sample Preparation Method that Reduces Signal Suppression Effects in the MALDI Analysis of Peptides. Anal. Chem. 2001, 73, 625-631.

31. March, J. Advanced Organic Chemistry. John Wiley and Sons: New York, 1985, p 334.

32. Steen, H.; Mann, M. Similarity Between Condensed Phase and Gas Phase Chemistry: Fragmentation of Peptides Containing Oxidized Cysteine Residues and Implications for Oroteomics. J. Am. Soc. Mass Spectrom. 2001, 12, 228-232.

33. Mo, W.; Yuliang, M.; Toshifumi, T.; Neubert, T. A. Sequencing of Oxidized Methionine Containing Peptides for Protein Identification. Rapid Commun. Mass Spectrom. 2000, 14, 2080-2081.

34. Medzihradszky, K. F.; Campbell, J. M.; Baldwin, M. A.; Falick, A. M.; Juasz, P.; Vestal, M. L.; Burlingame, A. L. The Characteristics of Peptide Collision-Induced Dissociation Using a High-Performance MALDI-TOF/TOF Tandem Mass Spectrometer. Anal. Chem. 2001, 72, 552-558. 